Available Online at http://journal.unismuh.ac.id/index.php/otoritas

Otoritas : Jurnal Ilmu Pemerintahan, 8 (1), April 2018, 1-16

\title{
Building a Ukrainian Identity in Odessa: Negotiation of Markers and Informal Nationalism
}

\author{
Abel Polese ${ }^{1,2 *}$ ) \\ ${ }^{1}$ School of Governance, Law, and Society, Tallin University, Narva mnt 2510120 Tallinn, Estonia. \\ ${ }^{2}$ Department of Law , Tallin University of Technology, Ehitajate tee 5, 12616 Tallinn, Estonia.
}

Received: 27 December 2017; Revised: 10 April 2018; Accepted: 13 April 2018

\begin{abstract}
A large and established body of literature on nation building in post-socialist spaces has initially put emphasis on state-centred construction of identity references and markers such as language, education or institutions and governance. In contrast, a recent stream of scholarship has attempted to bring agency into identity debates to propose new tools and approaches that can be used in the study of identity construction. This article is a further exploration of the latter position. It looks at the way identities are constructed, and renegotiated, at the everyday level, by ordinary people, by illustrating the competition between Russian and Ukrainian languages in Odessa, a Ukrainian city on the Black sea, to look at the synergy generated by the competition between local and national narratives.
\end{abstract}

Keywords: Language, Identity, National Identity, Odessa, Ukraine

How to Cite: Polese, A. (2018). Building a Ukrainian Identity in Odessa: Negotiation of Markers and Informal Nationalism. Otoritas : Jurnal Ilmu Pemerintahan, 8(1), 1-16.

Permalink/DOI: https://doi.org/10.26618/ojip.v8i1.1014

${ }^{*}$ Corresponding Author.

E-Mail : abel.polese@tlu.ee

Copyright (C) 2018, Otoritas : Jurnal Ilmu Pemerintahan, ISSN: 2088-3706 (Print), ISSN: 2502-9320 (Online) 
Available Online at http://journal.unismuh.ac.id/index.php/otoritas

Otoritas : Jurnal Ilmu Pemerintahan, 8 (1), April, 2018, 2

\section{INTRODUCTION}

The ever growing body of literature on nationalism, and nation building, exploring a actors, and tools, contributing to identity construction and consolidation at the national level (Gellner, 1984; Guibernau, 2006; Smith, 1991; Billig, 1995) has, since 1989 , been integrated by studies from the the post-socialist region. Often embedded in a Brubaker's framework, scholars of post-socialism have explored the relationship between language and identity (Arel, 1995; Kuzio, 1998), interpretations of national and ethnic markers (Laitin, 1998; Ehala, 2009) in the negotiation, and renegotiation, of a national identity. In contrast to the above statist approaches, an alternative stream of research has suggested switching focus onto cultural references identified, constructed or performed, by bottom actors. Bringing back agency into identity debates, scholars have explored the role of middle actors such as teachers or local leaders (Kerikmäe, 2001; Polese, 2013; Rodgers, 2007; Richardson, 2008; Troitiño, 2013, 2013b; WigglesworthBaker, 2016) in the redefinition of identity markers. Bringing this idea further, a new generation of scholars have been looking at the way official narratives on identity, constructed through macroprocesses by a state, can be questioned and renegotiated by everyday ways of living and practicing identity (Fabrykant, 2018; Gaufman, 2018; Kerikmäe, NymanMetcalf \& Papageorgiou, 2013; Pawłusz \& Seliverstova, 2016; Seliverstova, 2017).

Two disting approaches have emerged from the above tendency. One explores non-traditional tools used to construct a national identity. In this respect, studies have engaged with ways elections, cultural policies or mega projects may be a powerful, albeit sometimes unnoticed, way to redefine national identity or propose alternative identity markers (Danero Iglesias, 2017; Leonardis,
2016, Isaacs, 2016; Isaacs \& Polese, 2016; Menga, 2015; 2016; Ó Beachain, 2016; Ó Beachain \& Kevlihan, 2013; Ventsel, 2016). The other focusses on the way identity is constructed, and negotiated, through practice at the everyday level by ordinary citizens (Polese et al, 2017; Polese et al, 2018). Authors engaging with this framework have analysed the role of music, consumption and other practices not traditionally linked to identity construction (Bulakh, 2017; Datunashvili, 2017; Pawlusz, 2017; Pechurina, 2017; Astapova, 2017) to suggest that markers proposed by ordinary citizens, aware or not of their role, may play a significant role beyond state-inducted narratives.

This article brings further evidence to the above-mentioned paradigms by looking at the way identities are constructed, and renegotiated, at the everyday level, by ordinary people. It uses the case study of Odessa, a Ukrainian city on the Black sea, to look at the synergy generated by the competition between local and national narratives. The significance of the case is due to the fact that the city has initially adopted, since its creation Russian as one of the main languages for both written and oral communication. Language use in public places has remained unchallenged until 1991, when Ukraine became an independent and sovereign state that eventually decided to adopt a single state language - Ukrainian a thing that could pave the way to possible language or ethnically based conflicts. This risk had been already documented by debates on identity construction that, since the nineties, have been largely influenced by the increasing of ethnic conflicts, initially explored through the "nationalising the state" framework provided by by Brubaker (1996). National, religious and economic concerns have been brought to politics and used politically to gain extra support from the population. In some cases this renewed political competition benefited the country, or 
its society, as in the case of Poland, Czechoslovakia or Hungary. In other cases political competition prompted leaders to dwell on ethnic politics, such as in former Yugoslavia, resulting in ethnic tensions sometimes escalating into violence.

Sometimes political pluralism has facilitated a transition towards democratisation -like most of the Central European Countries and, to a certain extent, the Baltic countries and in Ukraine-, some other times transition has been smooth but is still incomplete and pluralism exists, though is not democratic -like in the case of Belarus or Russia.

As a result, over the past years, debates on management of multi-ethnic societies, and how to construct and maintain a national identity, have dramatically intensified. These studies have, however, largely downplayed the role of informal actors and practices in redefining national identity. As shown in this article, for one thing, the decision to make Ukrainian the sole state language, thus putting the majority of the Odessa population in the condition to speak a minority language, has not led very far in practice. Even more interestingly, possible conflicts - fomented by language or ethnic differences, have been put on hold for several years. In fact, this decision contrasted with the everyday practice of its inhabitants that kept on using Russian as main language of communication (Polese, 2009, 2013; Polese \& Wylegala, 2008; Richardson, 2008). The case study presented here is intended to suggest that informal renegotiation of policies may lead to a balance between national and local modes of governance, allowing each community to live, and frame, their identity the way best suits them.

\section{RESEARCH METHODS}

Empirically this article has been informed by data collected during a year of fieldwork in the city of Odessa during 2003-2004 and 2005-2006. Much has changed since then, with insurgency spreading across Ukrainian eastern regions and ethnic tensions between Russians and Ukrainians increasing in the city. Nonetheless, I consider the material still useful for at least two reasons.

First, I see the tensions between what have been defined "Russians" and "Ukrainians" not ethnic or linguistic but mostly political. True that Kremlin fans in Odessa, as in the rest of the country, are more likely to be Russian speakers, whilst Kiev supporters are Ukrainian speakers. But there is also a large amount of Russian speakers who support Ukraine politically and ideologically.

Second, and possibly more relevant to this article's goals, empirical evidence on competition between Russian and Ukrainian is not intended to explain the political evolutions of the country but a social phenomenon that is still visible. The use of language, as observed during fieldwork, is not necessarily backed up by a political credo but by a practical necessity to use the language one feels more comfortable with. It is used here to illustrate the case of a state demanding, from its citizens, something that they do not intend to provide and to show the role of individual agency in the renegotiation of state-led instructions.

The core empirical evidence for this article are 49 in-depth interviews. Informants, identified through snowball sampling, were met several times, to build trust relations, before being asked if they agreed to be interviewed (their identity was protected by anonimizing the data and changing their names).

The information gathered was then triangulated with the results of intensive observation carried out in 6 schools and in 2 cultural centers. The schools were selected to enable a comparison between the best schools (elite institutes that were more likely to comply with state instructions with regards to language use, and thus have effects on the identity of the pu- 
pils) with some basic schools, in which the state had no particular interest and that were left free to decide on the level of Ukrainization they wanted to reach. A full elaboration of the intensive observation in schools has became the core material for a separate article. However data were also used here to better interpret the material collected through interviews. The next session provides an overview of nation-building measures in Ukraine after 1991. The following ones present the empirical material collected at local schools and during the in-depth interviews, when the issues of plausibility and acceptance emerged.

\section{RESULTS AND DISCUSSION}

\section{Nation Building in Ukraine}

The successor states emerging from the collapse of three major federative states in Europe, the USSR, Czechoslovakia and Yugoslavia provided scholars with a large amount of material to resume the debates on nation building, started during the 1960s and somehow on hold at that time. Thanks to a new generation of scholars working on Ukraine, the number of studies on the country quickly increased. Kuzio $(1998,2001,2002)$, in particular, claimed the possibility to classify Ukrainian nation building as civic, as opposed to ethnic-based nationalizing state framework conceived by Brubaker (1996), also focusing on Eastern Europe, a few years before. He was quickly followed by a number of other scholars (Barrington, 1995; Janmaat, 2000; Latin, 1998; Schulman, 1999, 2002, 2003; Wolczuk, 2000) making thus Ukraine possibly the most post-Soviet country studied with regards to identity and nationbuilding.

What made Ukraine a particular case was the divergence between language and identity. Officially about ninety percent of the local population voted for independence, a plebiscite echoing the attitude towards the USSR present in other countries (i.e. the Baltics). However, only a fraction of those voting for independence had Ukrainian as their main language. This was the result not only of Sovietization policies but also, and possibly more important, of a preference accorded to Russian well before the October Revolution (Kravchenko, 1985). Ukrainian language became, however, one of the main points on the country's first president political agenda. Leonid Kravchuk introduced not only a number of laws in boosting the importance of Ukrainian. He even suggested a motion thanks to which Ukrainian presidents should display a sufficient command of the national language to be elected. Strategically adequate for a nation-building project, Kravchuk's rationale was contrasted by the reality of a country where Russian was widely spoken with peaks in the southern and eastern regions (Khmelko, 2004). The number of Ukrainian speakers, however, started raising. As a success of the nation building project, according to state narratives, as a consequence of some sort of "cheating the statistics" according to some scholars. Indeed, the 2001 census was widely criticizing for its methodology, failure to interview citizens in person and ethnic identity assigned on the base of the interviewer's impression, rather than the respondent's answer (Stebelsky, 2009). Still, as Shevel pointed out, endorsement of the Ukrainian state was done, by a growing number of citizens, through a claim to be native speakers of Ukrainian during the census interview, regardless of what language they would speak in reality.

Further laws highlighted the importance of Ukrainian, making it the sole language for official state documents and the main medium for instruction in schools in 1998. Ukrainian language teaching was the standard by default with exceptions allowed only in parts of the country where the number of ethnic Russians was overwhelmingly higher. Prac- 
tice was slow to follow theory (Arel, 1995). Nonetheless the number of preschools in Ukrainian rose from 51 percent in 1991 to 76 percent in 2000. Primary and secondary schools followed a similar pattern, increasing from 49 percent in 1991 to 70 percent in 2000 . Southern and eastern regions were slower in catching up (UCEPS, 2002) but, by 2002, the number of pupils studying in Russian had decreased to 25 percent. Changes were registered not only in the medium of instruction but also in the very content of the subjects to be taught, a thing that intrigued a few scholars over the years (Janmaat, 2005; Kuzio, 2001; Popson, 2001; Wolczuk, 2000). Ideologically, commitment to Ukrainian was shown by starting calling it "native language" (ridna mova) for all the students (Polese, 2010), regardless of which was their language in practice. Along schools, media broadcasting witnessed a real "language revolution" with Ukrainian becoming the main language for regional and national broadcasting in 2005.

\section{Ukrainization of the Educational Sector}

Collection of empirical data was intended to test the efficacity of the above measures. As a result, a first part of the fieldwork was conducted in schools, where intensive observation over several days was carried out. Once a teacher enters the classroom students will stand up in silence. In case, the teacher will address in Russian the noisy students to ask them to stop. Further to this, any technical information will be delivered in Russian until "the class begins" officially. The teacher will then try to speak, as much as possible, in Ukrainian, even translating what a student had just said in Russian into Ukrainian. They might also want to translate back into Russian something they just said in Ukrainian if they gather the impressions that students are not understanding sufficiently. Teachers are not necessarily Ukrainian native speakers.
Some words will come to their mind in Russian first but their task will be to give the impression that the overall class is conducted in Ukrainian, even when Russian words are used. When reacting to a question, students have two main options. They will speak Ukrainian if they can recall the answer from their textbook. They will otherwise use Russian if their answer results from their intuition or reasoning that is not necessarily taken from the book. The teacher might just accept an answer in Russian or translate it into Ukrainian with the goals of reminding the official language but also to expand the students' vocabulary. Both goals serve the function of educating children to be sensitive to the context and understand that they need to use the state language in official occasions.

Sometimes students, like all children, will be distracted by something, joke or simply talk to their neighbours. The teacher will then call for order in Russian in the majority of cases. They first use Ukrainian but, once this fails to persuade the students, they switch to Russian. Students might try to ignore the teacher in their official role but will find more difficult to do the same once the teacher proposes themselves as "one of us" thus speaking the same language and reminding the personal relationship that they have established with the children in the course of the year(s). When the class is over, and interaction becomes informal again, Russian will be preferred to Ukrainian to deliver the final instructions before ending the class. Homework is an exception and will be given in Ukrainian, reminding the student that this is the language they are supposed to study in.

There are several Ukrainian speaking villages around Odessa, some of them providing teachers to the city's schools. However, urban residents are more likely to have Russian as a first language and, once completed their studies, they are requested to teach in Ukrainian. In the 
course of my observations, only once I encountered a Ukrainian speaker teaching in Ukrainian but in many other cases I have witnessed the efforts of Russian speakers to comply with national regulations in terms of means of instruction. This is not only a desire to respect the rule but also a responsibility. Teachers know that their students will enter a job market where knowledge of Ukrainian is crucial and, by encouraging use of the national language they feel they increase the chances of their pupils to get a better job in the long run. A teacher once reported to me 'students are not native Ukrainian speakers; neither am I but we do our best.' (Polese, 2010)

In addition to this dual use, official narratives in public places tend to minimize the use of Russian in everyday contexts. Talking with an administrative of a major school, I hinted that the fact that "History of Odessa" was taught in Ukrainian could sound a paradox since most of the written sources and textbooks about the history of the city are in Russian. Initially she endorsed my statament, adding that in that school (Ukrainian already for 10 years) Russian, the local language, was widely used. I tried to push her statements futher but then she renegotiated, suggesting that, to the best of her knowledge, the teacher was using Ukrainian in her classes. She advocated for a gradual and flexible approach given that, in her understanding, not all students (and teachers) had come to realize that Ukrainian was the official state language at the time.

During observations in another school I came across a teacher admitting that its pupils often confused Russian and Ukrainian. He also recalled that, although classes were intended to be all in Ukrainian, the fact that pupils, and teachers, had a bad command of it pushed the use of Russian much father than the state would like to hear. After all, and this was also confirmed by other teachers a number of official books were available only in Russian with the exception of Ukrainian literature subjects, where Ukrainian speakers were often available.

Not only language practice seems to be distinct from how things should work in theory. Even more important is the existence of an unwritten code of communication. None of my informants were officially opposing linguisting change and the use of Ukrainian. They mentioned clearly that Ukrainian should be known, used and protected, being the official state language. In practice, Russian was given a permanent status of exception, meaning that use of Russian was advertised as incidental, due to a given moment and a given context. However, when this "incidental" use of Russian leads to its regular use in most, not to say all, situations, the social scientist start getting aware of the gap between theory and practice. Schools, and their staff, regularly work to build the impression that state instructions are abided and Ukrainian is largely used. A number of teachers know that they should be using Ukrainian and claim to do so, but switch to Russian as soon as this becomes possible or convenient, for instance, if both interlocutors of a conversation are Russian speakers, which happens quite often.

Little pressure is put on students to increase the occasions in which they use Ukrainian From the teachers' side, there seem to exist two channels of communication in the previous situation. Teachers are, in theory, civil servants. In this quality they represent the state and have to endorse official narratives and use Ukrainian or, at least, give the impression to be using Ukrainian when performing their duties. In the end education towards an attitude is as important as education towards knowledge. Pupils do not only learn notions but also how to behave in a society that expects them to speak Ukrainian during their official performing of duties. Being able to display knowledge 
of Ukrainian was a plus on people, and pupils, capacity to compete on the job market in the long run. However, people were not going to change their life habits to comply one hundred percent with state requirements.

The Ukrainian dimension is stressed at several occasions and in several schools that I visited with the exception of the Russian school chosen for observation where a clear borderline between the languages is drafted. While there are subjects (mostly literature and history of Ukraine) that are taught in Ukrainian, and the rest in Russian, pupils are nonetheless expected to have a good understanding and use of the language. Indeed, from the second year on, they are expected to be functional in Ukrainian. Interestingly enough, I managed to ask about the ethnic background of pupils and they all answered to be Ukrainian, to know, read and watch Ukrainian TV but they studied in Russian. Their linguistic choice did not deny the role of Ukrainian language in the country and the city. Paradoxically, it seemed to help them to construct parallel spaces where Russian and Ukrainian could co-exist and where, although their preference would go to Russian, the role of Ukrainian was acknowledged.

Observation in schools provided an opportunity to notice the possibility, at least in Odessa, to renegotiate informally state-led instructions on the language used in schools and official communication. Keeping in mind an official version of things where Ukrainian is the main language to use, Russian is used in the classroom, teachers' meetings, speaking with children's parents and in many other contexts. This can be lead to a situation where Ukrainian is barely used but people keep a positive attitude towards the language (Polese, 2011, 2011b).

The use of Ukrainian becomes thus functional to given an impression, to "construct a façade of Ukrainianess". Teachers and other state representatives thus carry out a sort of "mediation" between policy makers and policy takers (citizens). Teachers have agency not only on the use of language but also on the perspective they provide, interpretation of history and attitude towards national symbols (Polese, 2014; Richardson, 2008; Rodgers, 2007). Ukrainian and Russian, and their use, can then be regarded, rather than ethnic markers, a mean to distinguish official communication from unofficial one, public from private spaces. The impossibility to micro manage every single class, control every single teacher and their attitude provides extra space for a renegotiation of identity, and its boundaries. In the end the bottom line is not the use of Ukrainian for official communication and official time but the impression to be using Ukrainian. As long as people know that they should be doing Ukrainian, use of Russian may considered "an exception".

\section{Ukrainization of private spaces}

Are Odessans Ukrainian? To what extent? Are Odessans as Ukrainian as any other Ukrainian in the country, no matter whether from eastern or western regions? Are all Ukrainians Ukrainian the same way? Glancing through national surveys one could answer that people from Donetsk, Odessa and Lviv are Ukrainian, but a doubt might arise on to what extent Ukrainians give the same meaning to the word 'Ukrainian'. Whereas stimulations from the centre are similar for the whole country, the response of the peripheries may depend on a number of factors that rely on historical, social and geographical features.

Why somebody in Odessa should consider itself Ukrainian? I am not talking of those who have 'no escape' because born in Ukrainian families, Ukraine native speakers and attached to the Ukrainian soil. I refer to those 'in between' that are a consistent group in the city and in the country. Fournier (2002) call them 
'hybrid', Wilson (2002) use the expression 'grey zone'. What would be the motivation for change for those who are born from mixed marriages, who are divided between two or more identities, or are undecided, on whether to adopt a Ukrainian identity?

Reshaping of subjective identity criteria depends on two factors: plausibility and acceptance. In this respect the tipping model proposed by Laitin (1998) is extremely relevant but a model conceived for a number of cases does not necessarily fit a particular one. I use the term 'plausibility' as Schlee (2004) does, to refer to the capacity, and potentiality, to 'sell oneself' as native to other natives. This leads us to the second factor, acceptance, at personal and group level. At personal level, I address reshaping and reconstruction of personal and subjective memory, acceptation of national symbolism and the predisposition and willingness to 'betray' one's origins to pick up a new identity. I will illustrate some examples in the next section. At group level, it is relevant to explore the openness of other people to accept renegotiated identities and the willingness not to question or doubt of somebody's conversion once it happened.

\section{Plausibility}

Mikhail (24) considers himself as Ukrainian while his younger brother (21) does not, or not in full at least. Born to the same parents (a Russian father and a Ukrainian mother living in Odessa), the older brother moved to Kiev with his wife and child to work. Moving to Kiev, and then learning using Ukrainian for his dayto-day communication, was a milestone in Mikhail's life, who start feeling more and more Ukrainian to the point that his father felt betrayed, at some point. Eventually this became acceptable at the family level and even Mikhail's brother, when asked more in detail, admitted that he is confused and does not feel hundred per- cent Russian but also somehow Ukrainian.

This is not the only case, several informants seemed to have issued from "switching families", changing their nationality in the course of their life. Another Moldova-born informant, with Russian father and Russian-Ukrainian mother (born in Russian but in a Ukrainian village in northern Caucasus) had diverged from his brother's path becoming Ukrainian and living in Kiev, while his brother had remained in Russian and loyal to his Russian identity. He eventually got married in Kiev and his children feel Ukrainian.

Further interviews confirmed this ambiguous border. A 20-year old informant declared herself Ukrainia but admitted that, until she turned 16, she was convinced to be Russian. Her elder brother (26) declared himself Ukrainian claiming that his parents chose for him at the time of the national census. I had the chance to talk to their parents, who seemed confused themselves by the break-up of the Soviet Union, when everything was easier: they were all Soviet back then. Another informant (26 at the time of the interview) claimed to be Polish on the basis of some of his ancestors, in spite of having a declared Russian father and Ukrainian mother. When I inquired further, he admitted some kind of Ukrainian identity but, according to his father, whom I also interviewed, he is in fact Russian.

Why some transformations are smoother, or easier, than others? Is there a rule behind those patterns of behaviour? One point I make here is that people try to produce evidence to motivate their choice in a very singular way. The choice does not come from an inner analysis of all the elements in my body, followed by a rationale assessment on who I am but individuals make an emotional choice and then search for ground to motivate it.

Plausibility is quite important in the definition of an identity and it comes in two components, plausibility for the self and the others. If I my parents are from 
Available Online at http://journal.unismuh.ac.id/index.php/otoritas

Otoritas : Jurnal Ilmu Pemerintahan, 8 (1), April, 2018, 9

Russia and I was born there I might have some difficulties in convincing myself that I am Ukrainian. I could make up for this if I grew up there, have a Ukrainian passport or lived in the country long enough. But still, how easy it would be to 'forget' my origins? Or convince others that I am Ukrainian? In my case each of the above mentioned persons had enough evidence to declare at least three national identities and they choose the evidence they find most useful. In addition the answer to these questions also depends on the place I live in as in Odessa to be accepted as Ukrainian seems easier than in Lviv for instance (Polese \& Wylegala, 2008).

In many cases hearing that identity was connected to gratitude to their motherland, where informants had found their own dimension, pointed at the fact that emotional connections count, and quite a lot, in the choice of an identity. After all, in a place as mixed as Odessa, it is often possible to find out about an ancestor of a given (declared) ethnicity that will inform your own choice. In each individual there is much evidence and they may pick up the one they need to support their choice. Nation building, in this respect, is a bet: the bet to push people to pick up the 'right' evidence to feel part of the national community.

State attitude, however, counts. I might not feel more Ukrainian if I have a Ukrainian passport but I am more likely to feel Russian if I am refused a Ukrainian passport for some reason. In this respect, I consider helpful to the consolidation of national identity the openness of Ukraine to offer anyone living in the country in 1991 the chance to apply for citizenship, and then passport, regardless of their ethnic background.

The 'passport competition', still ongoing in Ukraine, is certainly not a model of civic nation building. Holding of a Ukrainian passport excludes any other citizenship so that people have to live Ukrainian one as exclusive and give up everything to get it, including the possibility to visit their home country (think of Bulgarian or Polish minorities who need a visa to go 'home'). Nonetheless the rule has been applied elastically and, despite having heard many times that people cannot get a second passport, I know a consistent number of people who have it, just keep it hidden. So far, thus, there is no reason to reject the Ukrainian state, as no choice is involved.

As Ukrainian citizens grow up, they will have two environments to face, the household and the outside one. At home the parents will have a consistent influence on him but this is not enough to define an identity, otherwise all my informants with proud Russian father or families would call themselves Russian. There is socialization outside the parents' sight, there is social life outside the family and cultural references or spreading of a national idea are also important.

It is certainly important that Ukrainian history be pro-Ukraine, but it is likewise important the very fact that there be a Ukrainian history subject in schools. Children can learn that Ukraine is a friend or enemy of Russia, but they will learn that they live under the Ukrainian roof, and this is not a thing to be neglected. From Weber on, it is acknowledged that definition of self is connected to the definition of the other and the very fact that a Ukrainian version exists is enough not to question which version of history we need as we have 'ours'. Language for the individual is also important but, rather than the frequency with which the national language is used, one shall look at the fact that it is there and people see it as a tool they can use. A Russian speaking friend once told me, after mentioning she was going to travel to Russia with other Ukrainians "great! we can talk to each other in the train and people will not understand us!" In spite of the fact that she does not uses it for daily communication, she -and many informants I have talked 
Available Online at http://journal.unismuh.ac.id/index.php/otoritas

Otoritas : Jurnal Ilmu Pemerintahan, 8 (1), April, 2018, 10

with- sees it as an asset, something 'we have and they do not have'. Is it really so important to current generations that Ukraine was conquered by Russia or entered an alliance in 1754 ? Or is it relevant that national and world history has a Ukrainian starting point, who is "right" or "wrong" in history?

"I do not see a major difference between Russia and Ukraine. Yes, Moscow is different but rural areas are quite the same in both countries. Indeed, my first time to Russia I left the train and noticed a Russian flag at the station. Apart from that, and judging by the panorama, I could as well be in Ukraine stil. (Sasha, 26. Ukrainian with Russian father)'.

Another informant reported: "I am Ukrainian. I speak Russian but I am Ukrainian and I first understood this when I went to Russia. I was in St. Petersburg, I could understand the language, the local culture but I did not feel at home (Eva 22, during a debate on identity)". Going abroad seemed a main milestone in the life of several informants, who had to face misconceptions and confusion between the two cultures, prompting them to take a side. A number of informants had indeed changed their attitude towards Ukrainian culture, language or even Russian language after a period abroad, especially if they were gathering with other people from the former USSR. Full challenging of the system of value or state role on citizens' life, like irredentism or separatism, does not really apply to Ukraine but people might oppose Ukraineness at a personal level. On what this will depend? Wanner (1998) talks of economic identities, in contrast with advocacy of national identity based on ethnic affiliation. Like often, the truth might lie in between, and literature on conflict can help us to understand. It is true that ethnic sentiments count in peoples' choice and economic elements are also relevant, But it is the combination of the two factors that directions people and re- inforces their choice. What happens if you do not go abroad? You do not become Ukrainian? Going abroad was the moment when people had to mature a choice but they might never have to face this choice and never ask themselves who they are. For instance, some informants admitted they never ask themselves the question. During my interviews I asked how the national conversion of the informer had happened. I was often indicated a very precise moment in the life of the interlocutor. This ranged from just traveling throughout Ukraine to entering the university and to travel to Russia to challenge anti-Ukrainian elders; but I would suggest that this was just the moment in which the person saw a process that was already over, when it took consciousness of the self. There were also a number of people who had not lived this process and refused to acknowledge Ukraine as their motherland. They could either refuse Ukraine or just ignore it.

If the question is why they should feel themselves Ukrainian an an answer may be 'why not?' Once they are born in Ukraine, their childhood memories are linked to the Ukrainian soil, the state has accepted them, provided them with education and, theoretically, is taking care of them, why they should refuse to acknowledge its role? One could imagine they are sitting on the fence and can choose where to jump, they can jump forth and follow the state and their motherland or back and shelter themselves into their origins. They can do this if they are unsatisfied with the state and this is a way to dissociate from it. The places that cannot be reached by the state or those that the state fails to protect are more likely to produce anti-Ukrainian feelings. The only two exceptions may be: they are unsatisfied with their situation at economic or emotional level. The (few) informants who refused the Ukrainian state projected on their motherland (mainly Russia) all the frustrations they had about 
Available Online at http://journal.unismuh.ac.id/index.php/otoritas

Otoritas : Jurnal Ilmu Pemerintahan, 8 (1), April, 2018, 11

their current situation, dreaming that 'there (in Russia) this would not happen.'

\section{Acceptance}

What is the engine of identity change? I would rely on intangible factors, like Connor (2004) but I would also suggest that, as long as an individual declares timidly itself Ukrainian, and other people start believing it, conversion may happen faster. In this lies the importance of 'not to question' who the other is. As long as a simple declaration prompts group acceptance, people will be more likely to see each other as Ukrainians.

'When I was in Lviv, a lady asked me about my wife's nationality. Used to the fact that in Odessa anybody can be Odessan or Ukrainian if their want, I said 'she is ours [nasha], she is Ukrainian: her father is Russian and her mother is half Azeri half Ukrainian. I was shocked by her attitude, she said that such person is definitely not a Ukrainian, only 'pure' Ukrainians are Ukrainian.'

As long as such attitude is present, conversion will be extremely difficult. Though this seemed a limited pheonomenon (Polese \& Wylegala, 2008). The fact that Odessans are more relaxed on ethnic origins of their fellow citizens should not be generalized. I cannot maintain here that everybody can be accepted as Odessan or Ukrainian as long as it fulfills some criteria but people can be clustered into two categories: 'native' and 'non-native'. That is to say, acceptance of a Ukrainian identity has some limits and, for the time being, physical traits are a serious constraint. There are ethnic groups that are deemed 'native' for the city and others not. A Ukrainian identity is plausible as long as it is declared by somebody who has physical traits of the native groups, and is a Russian native speaker, but what would happen if anybody with a non European appearance declared itself Ukrainian? One of my informants married a Ukrainian citizen who was an ethnic Ko- rean (and thus easily identifiable on the street). He told me:

"When we are in the street policemen tend to stop her and ask for her passport (Odessa is not Moscow and in 2 years I have never been stopped, despite being more dark-eyed and dark-haired than the average Slavic person), they tend not to believe that she is Ukrainian and control her quite long. When they go too far she timidly mentions she works for the tax inspection governmental service and she is immediately released. But this is not all. When she was in primary school she was informed that the school had 'lost' her birth certificate and she had to leave the school for that reason. The next day her mother (one of the most important persons in Odessa) made the right phone call and they immediately retrieved the certificate."

As a general tendency, elder generations were less likely to sympathize with the language in case they were not used to use it. Younger generations were much more positive, most of my students knew it and, if not, they at least declare they respected it. A similar pattern was found in younger generations when I was in schools and, at least officially, everybody seems to know Ukrainian, although they might get along with Russian much better. In the course of the interviews, nobody denied the Ukrainianess of Donetsk and Lviv but there was linguistic competition upon Ukrainian. This is not specific to Odessa and I have remarked it in other cities, where they tend to deny Ukrainian language skills of other cities. One will often hear that people from western Ukraine speak not really Ukrainian but a mix of Polish and Ukrainian whereas people in the east speak rather closer to Russian and people from Kiev mix everything. When asked about Odessa people dismiss the question with a smile. I once gained sympathy of a Ukrainian nationalist only thanks to my Odessa stay as he accepted my long stay in Odessa as the only 
Available Online at http://journal.unismuh.ac.id/index.php/otoritas

Otoritas : Jurnal Ilmu Pemerintahan, 8 (1), April, 2018, 12

'plausible' reason why I preferred to speak Russian rather than Ukrainian. Often, however, those differences are more imagined than real. When I was in Rivne a student told me that in the east they cannot speak proper Ukrainian. He told this in surzhyk. Likewise, a foreign journalist reported to have been surprised that in Donetsk they can speak Ukrainian. He had lived long in Moscow and went from Kiev to the Donetsk region to meet some miners. When asking about linguistic preferences he reported they immediately switched into Ukrainian, though I cannot be sure what 'kind of Ukrainian' they were using since to him everything would sound 'exotic'. They too claimed they hold the real language since, in the west, the language is too much Polish-polluted.

Ukrainian language may be regarded as a symbol and showing a positive attitude is more important than being able to speak it in the end (Polese \& Wylegala, $2008 b)$. One could also suggest that Odessans speak Ukrainian but one Odessan speaks Russian. Locals have a clear understanding of the distinction between state language for public use and use for private use. They just happen to expand, regularly, the sphere of the private to unofficial communication on the workplace, where Russian is used, apparently, "occasionally" or "incidentally" several times during the day, sometimes even constantly. However, the impression is often that Russian is used in a given moment as an exception (a Russian speaker entered the conversation, a Soviet movie is cited). Eventually, Russian speakers can use their language as long as they given the impression to be able to switch back to Ukrainian at any time. The quintessence of this attitude is the attitude of civil servants working in the city council, where most of the written and oral communication is in Russian. Ukrainian is used only when a document goes out to the central administration or other public offices. In these cases, workers will work to respect linguistic hierarchies and stick to the official communication protocol, look for one of the few Ukrainian speakers working in the office and get the document translated.

\section{CONCLUSION}

In addition to state-centred mechanisms for identity construction, a number of informal mechanisms for negotiation of national identity are in place, in Odessa as elsewhere. On the one hand, we have the way the elites, the state, and its institutions conceive national identity. They "imagine" the nation, in a more civic or ethnic manner, construct a national narrative intended to fit, and be applied in, all possible cases and geographical ares of the country. However, this narrative may sometimes contrast with some realities, situations, geographical areas, where the national narrative may be in conflict with the way locals perceive, and live, their own identity.

Renegotiation of identity at the top level would, most likely, entail a political confrontation between state and nonstate actors, between institutions and individuals - or better, organizations of individuals. However, there are ways this can be avoided and this article has shown one of them. If a state proposes a policy, without forcing or controlling to what extent citizens comply, and citizens create the impression to comply with the official discourse, without necessarily adopting it always and everywhere, then everyone seems satisfied. The state, and its institutions, do not feel challenged in their symbolic power by citizens, who officially abide to formal instructions and accept national narratives.

In practice, however, these narratives are renegotiated at the everyday level, when "an exception" is created and Russian is used instead of Ukrainian, "only here only now", creating a permanent state of exception, a sort of linguistic porto franco. The "Ukrainisation" of Odes- 
Available Online at http://journal.unismuh.ac.id/index.php/otoritas

Otoritas : Jurnal Ilmu Pemerintahan, 8 (1), April, 2018, 13

sa is based on a tacit compromise between the authorities and the citizens, between officers involved in local and national management of governance issues. The national parliament conceives a policy (or set thereof) that are then explained in general terms to technical managers at the regional and local level. Such policies get renegotiated first by the technocrats who need to translate them into instructions and passed to local authorities. Local authorities, in turn, will interpret and think of the best way to deliver these instructions to common citizens who, in turn, will only partially comply with the instructions, that are thus delivered but no control is applied, or no punishment is foreseen for the non-compliants, making possible informal renegotiation of policies at the local level. Further studies are needed before being able to lay out a theory of informal governance. However, I would suggest, this combination of elastic rules and limited control is allowing local leaders and actors to feel relatively free and making easier to accept a Ukrainian identity based on relatively flexible boundaries and markers.

\section{ACKNOWLEDGEMENT}

This research was supported by a Marie Curie International Research Staff Exchange Scheme Fellowship within the 7th European Community Framework Programme (grant no: PIRSES-GA-2012318961).

\section{REFERENCES}

Arel, D. (1995) "Language politics in independent Ukraine: Towards one or two state languages?." Nationalities papers, 23.3: 597-622.

Astapova, A. (2017). "How to pronounce 'Belarusian'? Negotiating identity through naming" in Polese, A., J. Morris, E. Pawlusz, O. Seliverstova (eds). (2017). Identity and Nation Building in Everyday Post-Socialist
Life: $131-145$

Barrington, L. (1995). The domestic and international consequences of citizenship in the Soviet successor states, Europe-Asia Studies, 47(5): 731-763.

Billig, M. (1995). Banal Nationalism. London: Sage.

Brubaker, R. (1996). Nationalism reframed: Nationhood and the national question in the new Europe. Cambridge: Cambridge University Press

Bulakh, T. (2017). Made in Ukraine: consumer citizenship during EuroMaidan transformations, in Polese, A., J. Morris, E. Pawlusz, O. Seliverstova (eds) Identity and Nation Building in Everyday PostSocialist Life (2017): 73-90

Connor, W. (2004). The Timeless of Nation, Nations and Nationalism, 1 (2): 35-47.

Danero Iglesias, J. (2017) Nuanced identities at the borders of the European Union: Romanians in Serbia and Ukraine in Polese, A., J. Morris, E. Pawlusz, O. Seliverstova (eds) Identity and Nation Building in Everyday Post-Socialist Life (2017): 146-160

Datunashvili, A. (2017) "The Georgian National Museum and the Museum of Soviet Occupation as loci of informal nation building" in Polese, A., J. Morris, E. Pawlusz, O. Seliverstova (eds) Identity and Nation Building in Everyday PostSocialist Life (2017): 52-70

Ehala, M. (2009). "The bronze soldier: Identity threat and maintenance in Estonia." Journal of Baltic Studies, 40 (1): 139-158.

Fabrykant, M. (2018) Why Nations Sell: Reproduction of Everyday Nation- 
Available Online at http://journal.unismuh.ac.id/index.php/otoritas

Otoritas : Jurnal Ilmu Pemerintahan, 8 (1), April, 2018, 14

hood through Advertising in Russia and Belarus, in Polese, A., 0. Seliverstova, E. Pawlusz and J. Morris (eds.) (2018) Informal Nationalism After Communism: The Everyday Construction of PostSocialist Identities. London: IB Tauris pp: 83-102

Fournier, A. (2002). Mapping Identities: Russian Resistance to Linguistic Ukrainization in Central and Eastern Ukraine. Europe-Asia Studies, 54(3) : 415-433

Gaufman, E. (2018). “Money Can't Buy It? Everyday Geopolitics in PostSoviet Russia" in Polese, A., O. Seliverstova, E. Pawlusz and J. Morris (eds.) (2018) Informal Nationalism After Communism: The Everyday Construction of PostSocialist Identities. London: IB Tauris pp: 104-120

Gellner, E. (1984). Nations and nationalism. New York: Cornell University Press

Guibernau, M. (2006). "National identity, devolution and secession in Canada, Britain and Spain." Nations and Nationalism, 12(1): 51-76.

Isaacs, R., \& Polese, A. (eds.) (2016). Nation Building and Identity in the Post-Soviet Space: New Tools and Approaches. London: Routledge.

Isaacs, R. (2016). "Cinema and NationBuilding in Kazakhstan" in Isaacs, R. and Polese, A. (eds.) (2016) Nation Building and Identity in the Post-Soviet Space: New Tools and Approaches. London: Routledge, pp: 136-156

Janmaat, J. G. (2005). "Ethnic and Civic Conceptions of the Nation in Ukraine's History Textbooks", European Education, 37(3): 20-37.

Janmaat, J. G. (2000). Nation-building in Post-Soviet Ukraine. Educational
Policy and the Response of the Russian Speaking Population. Utrecht et Amsterdam : Royal Dutch Geographical Society.

Kerikmae, T. (2001). Estonian Constitutional Problems in Accession to the EU in Kellermann et al. (eds) EU Enlargement: the Constitutional Impact at EU and National Level TMC Asser Instituut: The Hague, 291-300

Kerikmäe, T., Nyman-Metcalf, K., \& Papageorgiou, I. (2013). Is this really what I voted for? Legitimacy of European integration. Baltic Journal of Law \& Politics, 6(1), 45-62.

Khmelko, V. (2004). Lingvo-ethnichna struktura Ukrainy: regionalni osoblivosti ta tendentsii zmin za roki nezalezhnosti (The linguistic and ethnic composition of Ukraine: regional specificities and change after independence). Kiev: Kiev International Institute of Sociology.

Krawchenko, B. (1987). Social change and national consciousness in twentieth-century Ukraine. CIUS Press.

Kuts 0. (2004). Movna polityka v derzhatvochyskykh protsessakh Ukrainy (Language policy in Ukrainian state dynamics). Kharkiv: Kharkiv National University.

Kuzio, T. (2005). "Nation-building, History Writing and Competition over the Legacy of Kyiv Rus in Ukraine", Nationalities Papers, 33(1): 30-58.

Kuzio, T. (2001). Nationalising States' or nation-building: A Review of the Theoretical Literature and Empirical Evidence. Nations and Nationalism, 7(2):135-154.

Kuzio, T. (2000). Nationalism in Ukraine: Towards a New Framework. Politics, 20(2): 133-162. 
Available Online at http://journal.unismuh.ac.id/index.php/otoritas

Otoritas : Jurnal Ilmu Pemerintahan, 8 (1), April, 2018, 15

Kuzio, T. (1998) Ukraine: State and Nation -building. London: Routledge.

Laitin, D. (1998). Identity in Formation: The Russian-Speaking Populations in the New Abroad. Ithaca, Ithaca: Cornell University Press.

Leonardis, D. (2016). "Memory and Nation-Building in Georgia" in Isaacs, R. and Polese, A. (eds.) (2016) Nation Building and Identity in the Post-Soviet Space: New Tools and Approaches. London: Routledge, pp: 24-45.

Menga, F. (2016) "Public Construction and Nation-Building in Tajikistan" in Isaacs, R. and Polese, A. (eds.) (2016) Nation Building and Identity in the Post-Soviet Space: New Tools and Approaches. London: Routledge, pp: 193-205

Menga, F. (2015). Building a nation through a dam: the case of Rogun in Tajikistan. Nationalities Papers, 43(3): 479-494.

Ó Beacháin, D., \& Kevlihan, R. (2013). Threading a needle: Kazakhstan between civic and ethnonationalist state-building. Nations and Nationalism, 19(2): 337-356.

Ó Beacháin, D. (2016). "Elections and Nation-Building in Abkhazia" in Isaacs, R. and Polese, A. (eds.) (2016) Nation Building and Identity in the Post-Soviet Space: New Tools and Approaches. London: Routledge, pp: 206-225

Pawłusz, E., \& Seliverstova, O. (2016). Everyday Nation-Building in the Post-Soviet Space. Methodological Reflections. Studies of Transition States \& Societies, 8(1).

Pechurina, Anna (2017). "National food, belonging, and identity among Russian-speaking migrants in the UK." in Polese, A., J. Morris, E. Pawlusz, O. Seliverstova (eds) : 91
$-108$

Polese, A., O. Seliverstova, E. Pawlusz \& J. Morris (eds.) (2018). Informal Nationalism After Communism: The Everyday Construction of PostSocialist Identities. London: IB Tauris

Polese, A., J. Morris, E. Pawlusz., \& O. Seliverstova (eds.). (2017). Identity and Nationalism in Everyday PostSocialist Life. London: Routledge

Polese, A. (2014). "Patterns of identity formation in the post-Soviet space: Odessa as a case study" in Gonul Pultar (ed), Imagining Identities: Identity Formation in the Age of Globalization, Syracuse. NY: Syracuse University Press

Polese, A. (2013). "Ucrânia: a construção nacional entre o real e o imaginário" E-Cadernos 19 http://eces.revues.org/1588

Polese, A. (2011). Dichotomies Between Citizenship and Nationality: Reflections from the Ukrainian $\mathrm{Na}$ tion-building Experience, Politické Védy, 15(2): 48-63

Polese, A. (2011b). Ukraine: la construction nationale entre le réel et l'imaginaire in G. Rouet (ed.), Nations, Cultures et Entreprises en Europe, Paris: L'Harmattan

Polese, A. \& 0. Seliverstova (2011). Ucraina, fiabe senza frontiere" in, G. Motta (ed.) Raccontami una storia. Fiabe, leggende e miti nella memoria dei popoli, Roma: Franco Angeli

Polese, A., \& Wylegala, A. (2008). Odessa and Lvov or Odesa and Lviv: How Important is a Letter? Reflections on the "Other" in Two Ukrainian Cities. Nationalities Papers, 36(5): 787-814

Polese, A. (2010). The formal and the in- 
Available Online at http://journal.unismuh.ac.id/index.php/otoritas

Otoritas : Jurnal Ilmu Pemerintahan, 8 (1), April, 2018, 16

formal: Exploring 'Ukrainian' Education in Ukraine, Scenes from Odessa. Comparative Education, 46(1): 45-62

Polese, A., \& Wylegala, A (2008b). Sprache und Identitat: Reflexionen aus Odessa und Lwiw, Ukraine Analysen, 49: $13-17$

Polese, A. (2009). «Une version alternative de la révolution orange: transformations identitaires et nation building spontané», Sociologos 4 (Journal of the French Sociological Association), http:// socio-logos.revues.org/2315

Popson, N. (2001). The Ukrainian History Textbook: Introducing Children to the 'Ukrainian Nation'. Nationalities Papers 29(2): 326-350.

Richardson, T. (2008). Kaleidoscopic Odessa: History and place in contemporary Ukraine. Toronto: University of Toronto Press.

Rodgers, P. (2007). Compliance or contradiction'? Teaching 'History'in the 'New Ukraine. A view from Ukraine's Eastern Borderlands. Europe-Asia Studies, 59(3): 503519.

Seliverstova, 0. (2017). Consuming" national identity in Western Ukraine. Nationalities Papers 45 (1): 61-79.

Shevel, O. (2002). Nationality in Ukraine: Some Rules of Engagement, East European Politics and Society, 16 (2): 363-385.

Shulman, S. (2005). Ukrainian NationBuilding Under Kuchma. Problems of Post-Communism, 52(5): 32-47.

Smith, A. (1991). National identity. Reno: University of Nevada Press

Stebelsky, I. (2009). Ethnic SelfIdentification in Ukraine, 19892001: Why More Ukrainians and
Fewer Russians?. Canadian Slavonic Papers, 51(1): 77-100.

Storm, K. (2016). "Language, Law and Nation-Building in Georgia" in Isaacs, R. and Polese, A. (eds.) (2016). Nation Building and Identity in the Post-Soviet Space: New Tools and Approaches. London: Routledge, pp: 116-135

Troitiño, D. R. (2013). European Integration: Building Europe. New York: Nova Science Publishers Incorporated.

Troitiño, D. R. (2013b). The Current Economic Crisis of the EU: Genesis, Analysis and Solutions. Baltic Journal of European Studies, 3(1), 6-28.

Ventsel, A. (2016). Language, Economy and Nation-Building in the Republic of Sakha in Isaacs, R. and Polese, A. (eds.) (2016) Nation Building and Identity in the PostSoviet Space: New Tools and Approaches. London: Routledge, pp: 102-115

Wanner, C. (1998). Burden of Dreams. University Park: Pennsylvania State University Press.

Wigglesworth-Baker, T. (2016). Language, Schools and Nation-Building in Tatarstan in Isaacs, R. and Polese, A. (eds.) Nation Building and Identity in the Post-Soviet Space: New Tools and Approaches. London: Routledge, pp: 81-101

Wilson, A. (2002) "Elements of a Theory of Ukrainian Ethno-National Identities" Nations and Nationalism 8 (1):31-54.

Wolczuk, K. (2000). History, Europe and the 'National Idea': the 'Official' Narrative of National Identity in Ukraine, Nationalities Papers, 28 (4): 672-694. 